\begin{tabular}{|c|c|c|c|}
\hline & $\begin{array}{l}\text { Escola Superior } \\
\text { de Gestáo } \\
\text { Teconologia } \\
\text { [ipsantaréém] }\end{array}$ & KU & $\begin{array}{l}\text { ISSN 2029-7564 (online) } \\
\text { SOCIALINĖS TECHNOLOGIJOS } \\
\text { SOCIAL TECHNOLOGIES } \\
2013,3(1) \text {, p. } 115-129\end{array}$ \\
\hline
\end{tabular}

\title{
MEASURING AND MANAGING VALUE CO-CREATION PROCESS: OVERVIEW OF EXISTING THEORETICAL MODELS
}

\author{
Monika Skaržauskaitè \\ Mykolas Romeris University, Lithuania, skarzauskaite@mruni.eu \\ doi:10.13165/ST-13-3-1-08
}

\section{Abstract}

Purpose - the article is to provide a holistic view on concept of value co-creation and existing models for measuring and managing it by conducting theoretical analysis of scientific literature sources targeting the integration of various approaches. Most important and relevant results of the literature study are presented with a focus on changed roles of organizations and consumers. This article aims at contributing theoretically to the research stream of measuring co-creation of value in order to gain knowledge for improvement of organizational performance and enabling new and innovative means of value creation.

Design/methodology/approach. The nature of this research is exploratory - theoretical analysis and synthesis of scientific literature sources targeting the integration of various approaches was performed. This approach was chosen due to the absence of established theory on models of co-creation, possible uses in organizations and systematic overview of tools measuring/suggesting how to measure co-creation.

Findings. While the principles of managing and measuring co-creation in regards of consumer motivation and involvement are widely researched, little attempt has been made to identify critical factors and create models dealing with organizational capabilities and managerial implications of value co-creation. Systematic analysis of literature revealed a gap not only in empirical research concerning organization's role in co-creation process, but in theoretical and conceptual levels, too. 
Research limitations/implications. The limitations of this work as a literature review lies in its nature - the complete reliance on previously published research papers and the availability of these studies. For a deeper understanding of co-creation management and for developing models that can be used in real-life organizations, a broader theoretical, as well as empirical, research is necessary.

Practical implications. Analysis of the literature revealed limited existence of conceptual and, even more importantly, empirically tested models for managing co-creation. With importance of rising customers input, it is crucial to find ways of managing co-creation. This article can be considered as an initial phase into building conceptual model for measuring co-creation

Originality/Value. Even though co-creation of value with customers is a widely discussed topic in scientific world, little attempt has been made to find means for organizations to influence and manage customer's involvement. This work aims at reviewing existing models in order to present empirically tested model based on past research.

Keywords: co-creation, value, social technologies, models of co-creation.

Research type: literature review.

\section{Introduction}

The rapid growth of innovative Internet based information and communication technologies has created a new field of opportunities for organizations to reach their customers. This process has become easier than ever.

Customers have also been influenced by the rise of technologies and now are able not only to consume in new and diverse ways, but also to influence organizations when developing new products, improving existing ones and making experience of consuming better. Porta et al (2008:14) pointed out that it became easier for enterprises "to find and encourage those small groups of highly dedicated users who are willing to help other users get the most out of these sites, advocate the brand, spread the word and contribute content". Co-creation for business encompasses all of these processes and can be defined as a form of marketing or business strategy that centers on the generation and ongoing realization of mutual firm-customer value (Porta et al, 2008).

Besides the business world, the scientific world is also interested in co-creation, and since co- creation cannot be univocally attributed to one specific field, there have been publications from marketing, economics and communications departments of universities from all around the globe. Since 2004 the service-dominant (S-D) logic proposed by Lusch and Vargo (2004) has experienced a huge expansion both among academics and as a theory. Systematic literature research by Tanev et al. (2010) revealed four emerging research streams: (1) general management perspective; (2) new product development and innovation; (3) virtual customer environments; and (4) service science and service-dominant logic (SDL) of marketing. Also, new trend in scientific literature 
has emerged, which is to define and analyze the role and motivation of consumers in co-creation processes (Windisch, 2011; Füller, 2010; Hars \& Ou. 2002; Kristensson et al, 2007). Contrary to global trends, there is a limited amount of Lithuanian researches who concentrate on value co-creation and changed relationship between companies and consumers. Damkuviene (2009) carried out an in-depth analysis on client perceived relationship value with a high contact service organization. Aspects of service dominant logic were analyzed by Tijūnaitienè et al. (2009) and Sekliuckienè (2006).

Even though the co-creation of value with customers is a widely discussed topic in scientific world, little attempt has been made to find means for organizations to influence and manage customer's involvement. Therefore, the goal of this article is to provide a holistic view on concept of value co-creation and existing models for measuring it by conducting theoretical analysis of scientific literature sources targeting the integration of various approaches. Most important and relevant results of the literature study are presented with a focus on changed roles of organizations and consumers. This article aims at contributing theoretically to the research stream of measuring co-creation of value in order to gain knowledge for improvement of organizational performance and enabling new and innovative means of value creation. Findings of the research are considered to be an initial phase for author's further research into development of models and methods for measuring co-creation in order to get more effective management decisions.

\section{Customer as a Resource: Origins of Value Co-creation}

First articles on co-creation were published in the nineties (Urban et al., 1997; Ciccantelli \& Magidson, 1993; Dolan \& Matthews, 1993; Gilmore \& Pine, 1997; Peppers \& Rogers, 1993; Pine \& Gilmore, 1999; Herstatt \& von Hippel, 1992) focusing on consumer participation in providing services and product innovation. In modern scientific literature (Zwick et al, 2008; Protogerou et al, 2005; Payne et al, 2008) it is argued that the discourse of value creation has changed a bit and is aimed at working with the customers at their free will using different platforms and social technologies. Several authors have argued that the increased focus on intangible assets such as relationships, interactivity and mutual creation within wide range of business areas, has resulted in the move from a firm and goods-dominant (G- D) marketing paradigm to a paradigm which focuses on relationship marketing and customers as co-producers of value (Gummesson, 2008; Gronroos, 2008; Vargo \& Lusch, 2004). This change introduced a new actor in value creation field namely - a customer.

The change from being passive audience to becoming active players and co-creators of value was first noticed by Prahalad and Ramaswamy in 2000. Vargo \& Lusch (2004) examined the phenomenon further and observed the way marketing was studied and practiced during 20th century. The authors introduced concept of Service Dominant (SD) logic and customer-centricity, which emphasizes the development of relationships between consumers and organizations through dialogue and ongoing interaction. The S-D logic sees the customer as an operant resource, a resource capable of acting on other 
resources, a collaborative partner who co-creates value with the firm (Vargo, 2008) rather than being just a consultant or a resource for ideas. The concept of the S-D logic provides basis for understanding roots of co-creation.

\section{Process of Co-Creation}

In the traditional value creation process, companies and consumers had concrete roles. One was selling, other was purchasing. One was sending, other - receiving. In literature this type of value is often referred to as value-in-exchange. Products and services were sources of value, and this value was exchanged from the firm to the customer in the market place. The problem with this definition of value is that much of the attention is given to the producer (their acquisition of wealth) and the role of the consumer is undermined. The recent turn in the dominant logic of marketing has made this distinction disappear. Businesses and consumers have become no longer separate entities but performing various activities mutually, thus creating new form of value value-in-use. Thereby, the approach emphasizes the customer-organization interaction. In this manner, the customer-organization relationship is defined through a dialogical, personalized interaction, enabling a joint creation of value (Prahalad \& Ramaswamy, 2004b).

Inspired by the shift in customers role in the value creation process, many authors including Gummesson et al (2008, 2009), Cova and Dalli (2009), Baron \& Harris (2008), Payne et al (2007), Prahalad \& Ramaswamy (2000, 2004a,b) Gronroos (2011) and Ng et al (2010) analyzed the meaning and the nature of the new processes. Most cited and well-known definition of co-creation was provided by Prahalad and Ramaswamy (2000). They define co-creation as "a form of market or business strategy that emphasizes the generation and ongoing realization of mutual firm-customer value. It views markets as forums for firms and active customers to share combine and renew each other's resources and capabilities to create value through new forms of interaction, service and learning mechanisms." Unfortunately, this definition is rather long and obsolete since it does not represent all factors in the process. The works of the authors who analyzed co-creation were reviewed in the article "Co-Creation: a Typology and Conceptual Framework" by Payne et al. (2008). The analysis lead to suggestion that co-creation includes: (1) active involvement between at least two actors; (2) integration of resources that create mutually beneficial value; (3) willingness to interact and (4) a spectrum of potential form of collaboration. Based on these factors, Frow et al. define co-creation as "An interactive process involving at least two willing resource integrating actors which are engaged in specific form(s) of mutually beneficial collaboration, resulting in value creation for those actors."

Goornroos (2008) analyzed value co-creation process and provided three elements that lead to the outcome: customers sphere, suppliers sphere and joint sphere. A very similar approach was used by Payne et al (2008). The authors also supported process based perspective and provided a framework which features three sections: customer value- 
creating process (the processes, resources and practices that customers use to handle their activities), supplier value-creating processes (process, resources and practices used by a supplier to manage relationships with customers and other stakeholders) and encounter processes (processes and practices of interaction and exchange). A simplified illustration of the process is provided in Figure 1 "Process of Co-Creation" below. For a better understanding of the concept, main factors constituting it will be discussed: customer, organizational and joint spheres of co-creation process.

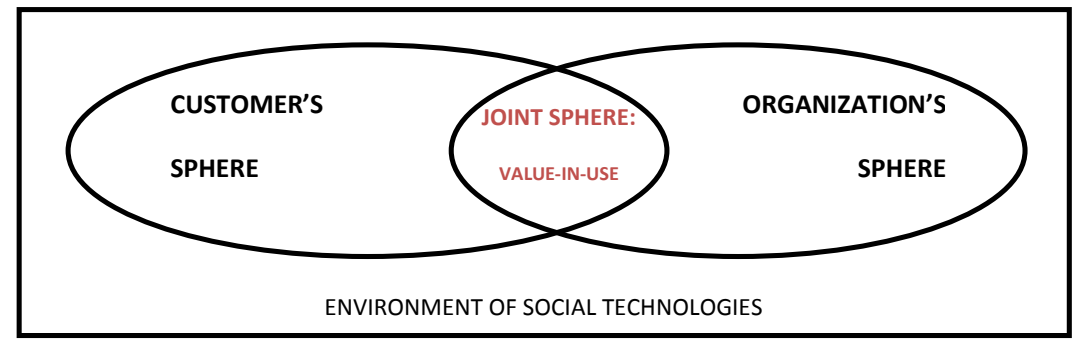

Source: developed by author, 2012

Figure 1. Process of Co-Creation developed by the author, 2012

What the Figure 1 illustrates is that in the process of co-creation both customer and organization are equally important. Through interaction, the organization gets an opportunity to influence the customer value creating process. During this direct interaction (in the environment of social technologies), each value creating process (customer process and organizational process) are merging into one integrated dialogical process. Both parties are operating inside each other's processes/spheres and have the chance to be active, coordinate actions, learn and directly influence each other (Grönroos, 2011).

It is noted that there has been a shift in understanding what customers are and what they should do. What literature review shows is that the role of organizations has changed, too. More importantly, in the value co-creation approach, the customer is the one who defines the value. This value is based on the experiences and perceptions while producing, consuming or using the service (value-in-use). Thereby, referring to Prahalad and Ramaswamy (2004a), the customer co-creation experience depends highly on particular individuals. Companies in fact should "creat[e] an experience environment in which customers can have an active dialogue and co-construct personalized experiences" (Prahalad and Ramaswamy 2004b: 8). Publications on the S-D logic and the value cocreation put the organization in control of the value co-creation, and the customer is invited to join this process as a co-creator (Heskett et al, 2002; Vargo \& Lusch, 2004). In the traditional value creation process, organizations have tried to manage the knowledge gap on consumer needs by engaging market research tools. Under this approach, "Successful innovation rests on first understanding customer needs and then developing products to meet those needs" (Hauser et al 2006:3). 


\section{Evaluation of Existing Theoretical Models for Measuring Value Co-Creation: Perspectives of Customers and Organizations}

As it has emerged from the analysis, customers have become more informed and should be treated as equal partners and organizations must find a new way how to address these changes successfully and to use knowledge gained from customer involvement. Therefore, this chapter will provide an overview of literature on existing theoretical models on co-creation offering theoretical models for measuring and assessing co-creation use from the perspectives of two involved parties, i.e. consumers and organizations.

Marketing scholars and practitioners have proposed a range of models and techniques for managing and measuring customers input. This includes creation of indexes and scales such as the Consumer Empowerment Index by Nrado, Loi, Rosati \& Manca (2011); the Dutch Customer Performance Index (DCPI) based on models of Rust et al (2004) and Verhoef et al (2007); Customer Value Co-Creation Behavior Scale by Yi and Gong (2010) and Customer Intimacy Grade (CIG) by Habryn et al (2010). Another approach used by researchers on co-creation is recommendations based on literature review and industry analysis (Füller et al, 2009; Rowley et al, 2007; Zwick et al, 2008). These papers are mostly conceptual in nature but their findings provide needed insights into the development and management of a customer community. Models of successful co-creation process are suggested by Habryn et al (2010), Etgar (2008), Ryssel et al (2004), Thomke \&Von Hippel (2002) and Maguire et al (2007). A more detailed review of the models is provided in Table 1 "Theoretical Models of Co-Creation on Customers Perspective".

Table 1. Theoretical Models of Co-Creation on Customers Perspective

\begin{tabular}{|l|l|l|}
\hline \multicolumn{1}{|c|}{ Researchers } & Focus of the study & \multicolumn{1}{c|}{ Practical implications } \\
\hline Nrado et al (2011) & $\begin{array}{l}\text { The Consumer } \\
\text { Empowerment } \\
\text { Index }\end{array}$ & $\begin{array}{l}\text { Measure of skills, awareness and engagement of } \\
\text { European consumers. }\end{array}$ \\
\hline $\begin{array}{l}\text { Based on models of } \\
\text { Rust et al (2004) and }\end{array}$ & $\begin{array}{l}\text { The Dutch Cus- } \\
\text { tomer Performance } \\
\text { Index (DCPI) }\end{array}$ & $\begin{array}{l}\text { Comparison based on two perspectives of } \\
\text { company's customer performance: (1) value a } \\
\text { company creates for their customers (2) value } \\
\text { a company creates for themselves with their } \\
\text { customers. }\end{array}$ \\
\hline Yi and Gong (2010) & $\begin{array}{l}\text { Customer Value } \\
\text { Co-Creation Be- } \\
\text { havior Scale }\end{array}$ & $\begin{array}{l}\text { The scale comprises two dimensions: } \\
\text { customer participation behavior and customer } \\
\text { citizenship behavior. It is useful for } \\
\text { evaluating and rewarding customer } \\
\text { performance. }\end{array}$ \\
\hline
\end{tabular}




\begin{tabular}{|c|c|c|}
\hline Habryn et al (2010) & $\begin{array}{l}\text { Customer Intimacy } \\
\text { in B2B Services }\end{array}$ & $\begin{array}{l}\text { Suggested approach should improve the } \\
\text { systematic analysis of customer intimacy in } \\
\text { organizations, leverage the customer knowledge } \\
\text { scattered throughout the } \\
\text { organization and enable benchmarking and } \\
\text { focused investments in customer } \\
\text { relationships. }\end{array}$ \\
\hline Füller et al (2009) & $\begin{array}{l}\text { Consumer } \\
\text { Empowerment } \\
\text { Through Internet- } \\
\text { Based Co-Creation }\end{array}$ & $\begin{array}{l}\text { Provide recommendations on how to design } \\
\text { compelling virtual new product co-creation } \\
\text { experience. }\end{array}$ \\
\hline Rowley et al (2007) & $\begin{array}{l}\text { Customer com- } \\
\text { munity and co- } \\
\text { creation }\end{array}$ & $\begin{array}{l}\text { Provides insights into the development and } \\
\text { management of customer community, informing } \\
\text { about product innovation and engaging } \\
\text { customers in the co-creation of consumption } \\
\text { experience. }\end{array}$ \\
\hline Zwick et al (2008) & $\begin{array}{l}\text { Co-creation and } \\
\text { new marketing } \\
\text { govern-mentality }\end{array}$ & $\begin{array}{l}\text { Recommendations for firms how to enhance } \\
\text { cooperation with customers. }\end{array}$ \\
\hline Etgar (2008) & $\begin{array}{l}\text { Consumer } \\
\text { Co-Production } \\
\text { Process }\end{array}$ & $\begin{array}{l}\text { Managers can use it to divide consumers ac- } \\
\text { cording to their tendencies to engage in } \\
\text { co-creation and suggest bases for developing } \\
\text { corresponding offers of co-production possibili- } \\
\text { ties which focus on diverse consumer benefits. }\end{array}$ \\
\hline Ryssel et al. (2004) & $\begin{array}{l}\text { Impact of IT on } \\
\text { trust, commitment } \\
\text { and value creation } \\
\text { in } \\
\text { business } \\
\text { relationships }\end{array}$ & $\begin{array}{l}\text { The findings give a new insight into the role } \\
\text { of information technology in value-creation in } \\
\text { business-to-business relationships. }\end{array}$ \\
\hline $\begin{array}{l}\text { Thomke \&Von Hip- } \\
\text { pel (2002) }\end{array}$ & $\begin{array}{l}\text { Customers as } \\
\text { Innovators: A New } \\
\text { Way to Create } \\
\text { Value }\end{array}$ & $\begin{array}{l}\text { Model of five steps are required for turning } \\
\text { customers into innovators. }\end{array}$ \\
\hline $\begin{array}{l}\text { Maguire et al. } \\
(2007)\end{array}$ & $\begin{array}{l}\text { Identifying the } \\
\text { range of customer } \\
\text { listening tools }\end{array}$ & $\begin{array}{l}\text { Provided qualitative tools can be used to add } \\
\text { understanding and gain an insight into } \\
\text { customers. }\end{array}$ \\
\hline
\end{tabular}

Source: developed by the author, 2013

Unfortunately and contrary to a wide variety of tools measuring consumer performance in co-creation, literature on organizations performance and managerial implications is rather limited. These tools are reviewed in this chapter and are explained in more detail in Table 2 "Theoretical Models of Co-Creation in Organizational and Management Contexts". Even though significant research has been conducted on the processes of the value co-creation, most of these studies focus on B2B relationship. Study by Ng, Nudurupati, Tasker (2010) introduced the concept of outcome-based 
contracting $(\mathrm{OBC})$ as the mechanism for firms to focus on delivering value-in-use, but attributes/factors provided are closely related to business cooperation (behavioral alignment, process alignment). Walter \& Ritter (2003) proposed theoretical framework of value drivers by discussing the impact of adaptation, trust, and commitment on valuecreating functions, but even though it has been tested empirically, it only applies to preconditions of the value co-creation with business partners of organizations.

Payne et al (2008) and Grissemann and Stockburger-Sauer (2012) discussed some strategic dimensions of co-creation and found out that there are almost no empirically based theoretical models, especially with the focus on strategic importance. The research by Grissemann and Stockburger-Sauer (2012) examined organization's role in co-creation and support to customers but their focus was only on one company in travel industry. Payne et al (2008) proposed a conceptual framework consisting of three main components: (1) customer value-creating processes; (2) supplier value-creating processes; and (3) encounter processes. Even though conceptual model is based on fieldresearch, it is still very hard to measure the processes and to get "hard" data. According to the authors of the model, it can be used for developing practices for organizations to identify opportunities for communication, service and usage encounters that support the co-creation of value.

Organizational sphere of co-creation process is a place where companies provide means for customers to create value. To build these means and facilitate environment for co-creation, Prahalad and Ramaswamy (2004) suggested theoretical model of four building blocks - dialogue, access, risk and transparency (DART). It can also be noted that the DART model focuses mainly on interaction aspects of the co-creation processes. Tapscott \& Williams (2006) offered three more important factors for successful (customer) co-creation for the internal organization of the company. To be able to successfully use 'external ideas' from the customer co-creation into the company, an appropriate culture, a good overview and planning, correct capability and skills should exist. Prahalad and Ramaswamy (2004a) developed a theoretical model of building blocks necessary to facilitate a co-creation environment; however, additional practical guidance on the topic of co-creation does not appear in the literature. The same applies to Tapscott \& Williams (2006) model. Therefore, the literature review revealed that most of the research based on these two models largely relies on qualitative and limited number of descriptive case studies.

Table 2. Theoretical Models of Co-Creation in Organizational and Management Contexts

\begin{tabular}{|l|l|l|}
\hline \multicolumn{1}{|c|}{ Researcher } & \multicolumn{1}{|c|}{ Focus of the study } & \multicolumn{1}{c|}{ Practical implications } \\
\hline $\begin{array}{l}\text { Ng, Nudurupati, } \\
\text { Tasker (2010) }\end{array}$ & $\begin{array}{l}\text { Value Co-Creation in } \\
\text { Business-to-Business } \\
\text { Service }\end{array}$ & $\begin{array}{l}\text { It presents seven generic attributes of value } \\
\text { co-creation (AVCs) essential for the capability } \\
\text { to deliver value-in-use, which is only valid for } \\
\text { B2B. }\end{array}$ \\
\hline $\begin{array}{l}\text { Walter \& Ritter } \\
(2003)\end{array}$ & $\begin{array}{l}\text { Value-creating func- } \\
\text { tions of customer } \\
\text { relationships }\end{array}$ & $\begin{array}{l}\text { Theoretical framework of value drivers by } \\
\text { discussing the impact of adaptation, trust and } \\
\text { commitment on value-creating functions. }\end{array}$ \\
\hline
\end{tabular}




\begin{tabular}{|l|l|l|}
\hline $\begin{array}{l}\text { Payne, Storbacka } \\
\text { \& Frow (2008) }\end{array}$ & $\begin{array}{l}\text { Centrality of processes } \\
\text { in co-creation }\end{array}$ & $\begin{array}{l}\text { Conceptual framework consisting of three } \\
\text { main components: (1) customer value-cre- } \\
\text { ating processes; (2) supplier value-creating } \\
\text { processes and (3) encounter processes. It can } \\
\text { be used for mapping the end-user's processes } \\
\text { and practices for organizations to identify } \\
\text { opportunities for communication, service and } \\
\text { usage encounters that support the co-creation } \\
\text { of value. }\end{array}$ \\
\hline $\begin{array}{l}\text { Grissemann, } \\
\text { (2012) }\end{array}$ & $\begin{array}{l}\text { Customer co-creation } \\
\text { in travel services }\end{array}$ & $\begin{array}{l}\text { It examines company's support as one select- } \\
\text { ed driver of co-creation, customer loyalty and } \\
\text { customer expenditures as selected outcomes } \\
\text { of co-creation. }\end{array}$ \\
\hline $\begin{array}{l}\text { Prahalad \& Ra- } \\
\text { maswamy (2004) }\end{array}$ & DART building blocks & $\begin{array}{l}\text { According to the authors, the origin of this } \\
\text { shift lies in the increasing bargaining power of } \\
\text { buyers due to the emergence of communica- } \\
\text { tion between customers. }\end{array}$ \\
\hline $\begin{array}{l}\text { Tapscott \& Wil- } \\
\text { liams (2006) }\end{array}$ & $\begin{array}{l}\text { Internal organizational } \\
\text { factors fostering co- } \\
\text { creation }\end{array}$ & $\begin{array}{l}\text { Proposed set of internal attributes (appropriate } \\
\text { culture, good overview and planning, correct } \\
\text { capability and skills) that could create co- } \\
\text { creation mindset in organization and success- } \\
\text { ful outcomes of the process. }\end{array}$ \\
\hline
\end{tabular}

Source: developed by the author, 2013

\section{Conclusions}

The analysis of scientific sources has revealed fundamental change in marketing theory and practice, i.e. because of the application of social technologies, customers have become more informed and involved in the creation and development of products and services. It has been found out that successful value co-creation always takes place in deep interactions between the company and the customers and their resource integration. The analysis lead to suggestion that value co-creation includes: (1) active involvement; (2) integration of resources that create mutually beneficial value; (3) willingness to interact and (4) a spectrum of potential form of collaboration. In the process of co-creation both customer and organization are equally important. Through interaction, the organization gets an opportunity to influence the customer value creating process. During this direct interaction (in the environment of social technologies), each value creating processes (customer process and organizational process) are merging into one integrated dialogical process.

With the exception of the DART model, enabling a company to engage more effectively with consumers as co-creators, and Tapscott \& Williams work on internal factors fostering co-creation, the overview of existing models has revealed a gap not only in the theoretical, but, more importantly, in the empirical research concerning firm's role in the co-creation process. These two works came closest to providing 
practical but limited advice through the development of building blocks of interactions between the firm and customers that are necessary for the process of co-creation. Existing models are based on a small number of case studies and qualitative data which is not always appropriate when building measuring tools. In addition to that, most of the studies provide conceptual models with no empirical evidence at all. The need for more research and empirical studies that would contribute to measuring and managing co-creation has been noticed not only by the author of this article, but also by a number of marketing researchers like Warnke, Weber and Leitner (2008), Nambisan and Baron (2009), and Bolton (2006). Therefore, there is an opportunity to make use of the theoretical knowledge on the topic of co-creation and to build practical insights. As famous marketing writer Drucker (1986) noted, "If you can't measure it, you can't manage it".

\section{References}

Ballantyne, D. \& Varey, R. The ServiceDominant Logic and the Future of Marketing. Journal of the Academy of Marketing Science. 2008, 36: 11-14.

Baron, S. \& Harris K. Consumers as Resource Integrators. Journal of Marketing Management. 2008, 24: 1-2, 113-130.

Bolton, R. \& Saxena-Iyer, S. Interactive Services: a Framework, Synthesis and Research Directions. Journal of Interactive Marketing. 2009, 23: 91-104.

Bolton, R. N. Foreword. In R. F. Lusch \& S. L. Vargo (Eds.). The Service Dominant Logic of Marketing: Dialog, Debate and Directions (pp. ix-xi). Armonk, NY: M.E. Sharpe, 2006.

Bowonder, B.; Dambal, A.; Kumar, S. \& Shirodkar, A. Innovation Strategies for Creating Competitive Advantage. ResearchTechnology Management. 2010, 53(3): 19-32. Brohman, M.; Piccoli, G.; Martin, P.; Zulkernine, F.; Parasuraman, A. \& Watson, R. A Design Theory Approach to Building Strategic Network-Based Customer Service Systems. Decision Sciences. 2009, 40(3): 403-430.

Ciccantelli, S. \& Magidson, J. From Experience: Consumer Idealized Design: Involving Consumers in the Product Development Process. Journal of Product Innovation Management. 1993, 10(4): 341-347.
Cova, B. \& Dalli, D. Working Consumers: The Next Step in Marketing Theory? Marketing Theory. 2009, 9(3): 315- 339.

Cova, B. \& Salle, R. Marketing Solutions in Accordance With the S-D Logic: CoCreating Value With Customer Network Actors. Industrial marketing management. 2008, 37: 270-277.

Damkuvienè, M. Client Perceived Relationship Value With a High Contact Service Organization. Doctoral Dissertation. Kaunas University of Technology, Kaunas, 2009.

Dolan, R. J. \& Matthews, J. M. Maximizing the Utility of Customer Product Testing: Beta Test Design and Management. Journal of Product Innovation Management. 1993, 10(4): 318-330.

Dong, B.; Evans, K. \& Zou, S. The Fffects of Customer Participation in Co-Created Service Recovery. Journal of the Academy of Marketing Science. 2008, 36: 123-137.

Droge, C.; Stanko, M. \& Pollitte, W. Lead Users and Early Adopters on the Web: The Role of New Technology Product Blogs. Journal of Product Innovation Management. 2010, 27: 66-82.

Drucker, P. F. Managing for Results, II ed. New York: HarperBusiness, 1986.

Edvardsson, B.; Enquist, B. \& Johnston, R. Cocreating Customer Value Through 
Hyperreality in the Prepurchase Service Experience. Journal of Service Research. 2005, 8: 149-161

Etgar, M. Co-Production of Services, Ch. 11 in Lusch, R. \& Vargo, S., Eds. The service Dominant Logic of Marketing. Armonk, NY: M. E. Sharpe Inc., 2006.

Etgar, M. A Descriptive Model of the Consumer Co-Production Process. Journal of the Academy of Marketing Science. 2008, 36: 97-108.

Ferguson, R. \& Paulin, M. Customer Sociability and the Total Service Experience: Antecedents of Positive Word-of-Mouth Intentions. Journal of Service Management. 2010, 21(1): 25-44.

Franke, N. \& Schreier, M. Product Uniqueness as a Driver of Customer Utility in Mass Customization. Marketing Letters. 2008, 19(2): 93-107.

Füller J.; Mühlbacher H.; Matzler K. \& Jawecki G. Consumer Empowerment Through Internet-Based Co-Creation. Journal of Management Information Systems. 2009, 26(3): 71-102.

Füller, J. Refining Virtual Co-Creation from a Consumer Perspective. California Management Review. 2010, 52(2): 98-122.

Gilmore, J. H. \& Pine, B. J. Beyond Goods and Services. Strategy \& Leadership. 1997, 25(3): 10-17.

Grönroos, C. Service Logic Revisited: Who Creates Value? And Who Co-Creates? European Business Review. 2008, 20(4): 298-314.

Grönroos, C. Value Co-Creation in Service Logic. A Critical Analysis. Marketing Theory. 2011, 11(3).

Lusch R.F.; Gummesson E. \& Vargo S. Transitioning from Service Management to Service-Dominant Logic: Observations and Recommendations. International Journal of Quality and Service Sciences. 2010, 2(1): 8-22.
Gummesson, E. Extending the New Dominant Logic: From Customer Centricity to Balanced Centricity. Commentary for Special Issue of The Journal of the Academy of Marketing Science JAMS. 2008, 36(1): 15-17.

Gummesson, E. \& Francesco P. B2B is not an Island. Journal of Business \& Industrial Marketing. 2009, 24(5/6): 337-50.

Habryn; Blau; Satzger \& Kolmel. Towards a Model for Measuring Customer Intimacy in B2B Services. First International Conference, IESS 2010. Geneva, Switzerland, February 17-19, 2010. Revised Papers. 2010: 1-14.

Hars, A. \& Ou, S. Working for Free? Motivations for Participating in OpenSource Projects. International Journal of Electronic Commerce. 2002, 6(3): 25-39.

Hauser J.; Gerard J.T. \& Griffin A. Research on Innovation: A Review and Agenda for Marketing Science. Marketing Science. 2006, 25: 686-717.

Herstatt, C. \& von Hippel, E. From Experience: Developing New Product Concepts via the Lead User Method: A Case Study in a „LowTech“ Field. Journal of Product Innovation Management. 1992, 9(3): 213-221.

Heskett, J. L.; Sasser, W. E. Jr. \& Schlesinger, L.A. The Value Profit Chain: Treat Employees Like Customers and Customers Llike Employees. New York: The Free Press, 2002.

Jaworski \& Kohli. Co-Creating the Voice of the Customer, Ch. 8 in R. Lusch \& S. Vargo, Eds. The Service Dominant Logic of Marketing. Armonk, NY: M. E. Sharpe, 2006.

Kohler, T.; Matzler. K. \& Fuller, J. AvatarBased Innovation: Using Virtual Worlds for Real-World Innovation. Technovation. 2008, 29: 395-407

Kristensson P.; Matthing J. \& Johansson N. Key Strategies for the Successful Involvement of Customers in the Co-Cretaion of New Technology-Based Services. International Journal of Service Industry Management. 2008, 19(4): 474-491. 
Maglio, P. \& Spohrer, J. Fundamentals of Service Science. Journal of the Academy of Marketing Science. 2008, 36: 18-20.

Maguire, S.; Koh, S. C. L. \& Huang, C. Identifying the Range of Customer Listening Tools: a Logical Pre-Cursor to CRM? Industrial Management \& Data Systems. 2007, 107(4): 567-586.

Michel, S.; Brown, S. W. \& Gallan, A. S. An Expanded and Strategic View on Discontinuous Innovations: Deploying a Service-Dominant Logic of Marketing. Journal of the Academy of Marketing Science. 2008, 36(1): 54-66.

Michel, S.; Brown, S.W. \& Gallan, A. S. Service-Logic Innovations: How to Innovate Customers, not Products. California Management Review. 2008, 50(3): 49.

Midgley, D. Co-Creating the Innovation With Customers, Ch. 5. The Innovation Manual Integrating Strategies and Practical Tools for Bringing Value Innovation to the Market. Chichester, UK: John Wiley \& Sons, 2009, 143-190.

Nambisan, S. \& Baron, R. Interactions in Virtual Customer Environments: Implications for Products Support and Virtual Customer Relationship Management. Journal of Interactive Marketing. 2007, 21(2): 42-62.

Nambisan, S. \& Nambisan, P. How to Profit From a Better 'Virtual Customer Environment'. MIT Sloan Management Review. 2008, 49(3): 53-61.

Nambisan, S. Virtual Customer Environments: IT-Enabled Customer Co-Innovation and Value Co-Creation, in Nambisan, S. (Ed.). Information Technology and Product Development - Annals of Information Systems. 2009, 5(2): 109-127.

Nambisan, S. \& Baron, A. Virtual Customer Environments: Testing a Model of Voluntary Participation in Value Co-Creation Activities. Journal of Product Innovation Management. 2009, 26: 388-406.

Ng I.; Nudurupati S. \& Tasker, P. Value CoCreation in the Delivery of Outcome-Based
Contracts for Business-to-Business Service. 2010.

Ng, I.; Maull, R. \& Yip, N. Outcome-Based Contracts as a Driver for Systems Thinking and Service-Dominant Logic in Service Science: Evidence From the Defense Industry. European Management Journal. 2009, 27: 377- 387.

Ngo, L. V. \& O'Cass, A. Creating Value Offerings via Operant Resource-Based Capabilities. Industrial Marketing Management. 2009, 38: 45-59.

Nrado; Loi; Rosati \& Manca. (2011) The Consumer Empowerment Index. JRC Scientific and Technical Reports. [interactive]. [accessed on 10-10-2012]. < http://ec.europa.eu/consumers/consumer empowerment/docs/JRC_report_consumer_ empowerment_en.pdf $>$.

O'Hern, M. \& Rindfleisch, A. Customer CoCreation: A Typology and Research Agenda. Review of Marketing Research. 2010, 6: 84106.

Ostrom, A.; Bitner, M.; Brown, S.; Burkhard, K.; Goul, M.; Smith-Daniels, V.; Demirkan, H. \& Rabinovich, E. Moving Forward and Making a Difference: Research Priorities for the Science of Service, Journal of Service Research. 2010, 13(4): 4-36.

Payne, A.F.; Storbacka, K.; Frow, P. \& Knox S. Co-Creating Brands: Diagnosing and Designing the Relationship Experience. Journal of Business Research. 2009, 62(3): 379-389.

Payne, A.F.; Storbacka, K. \& Frow, P. Managing the Co-Creation of Value. Journal of the Academy of Marketing Science. 2008, 36(1): 83-96.

Peppers; D. \& Rogers, M. The One to One Future. Building Relationships One Customer at a Time. New York: Currency Doubleday, 1993.

Pine, B. J. \& Gilmore, J. H. The Experience Economy: Work Is Theatre \& Every Business a Stage. Boston: Harvard Business School Press, 1999. 
Porta, M.; House, B.; Buckley L. \& Blitz, A. Value 2.0 - Eight New Rules for Creating and Capturing Value from Innovative Technologies. Strategy and Leadership. 2008, 36(4): 10-18.

Prahalad, C. K. \& Krishnan, M.S. The New Age of Innovation. New York: McGraw Hill, 2008.

Prahalad, C. K. \& Ramaswamy, V. Co-Opting Customer Competence. Harvard Business Review. 2000: 79-87.

Prahalad, C.K. \& Ramaswamy, V. The New Frontier of Experience Innovation. MIT Sloan Management Review. 2003, 44(4): 1218.

Prahalad, C.K. \& Ramaswamy, V. Co-Creating Unique Value With Customers. Strategy \& Leadership,.2004a, 32(3): 4-9.

Prahalad, C.K., \& Ramaswamy, V. The Future of Competition: Co-Creating Unique Value With Customers. Boston, MA: Harvard Business School Press, 2004b.

Protogerou, A.; Caloghirou, Y. \& Lioukas, S. Dynamics of Industry and Innovation: Organizations, Networks, and Systems. Paper presented at the DRUID Tenth Anniversary Summer Conference, Copenhagen, 2005.

Ramaswamy, V. \& Gouillart, F. Building the Co-Creative Enterprise. Harvard Business Review. 2010: 100-109.

Ramaswamy, V. Leading the Transformation to Co-Creation of Value. Strategy \& Leadership. 2009, 37(2): 32-37.

Roberts, D.; Bake, S. \& Walker, D. Can We Learn Together? Co-Creating With Customers. International Journal of Market Research. 2005, 47(4): 407-427.

Romero, D. \& Molina, A..Value Co-Creation and Co-Innovation: Linking Networked Organisations and Customer Communities. Leveraging Knowledge for Innovation in Collaborative Networks. IFIP Advances in Information and Communication Technology. 2009, 307: 401-412
Rowley J.; Kupiec-Teahan B. \& Leeming E. Customer Community and Co-Creation: A Case Study. Marketing Intelligence \& Planning. 2007, 25(2): 136-146.

Rust, R. T.; Lemon, K. N.; Zeithaml, V. A. Return on Marketing: Using Customer Equity to Focus Marketing Strategy. Journal of Marketing. 2004, 68(1): 109-127

Ryssel, R.; Ritter, T. \& Gemunden, H.G. The Impact of Information Technology Deployment on Trust, Commitment and Value Creation in Business Relationships. The Journal of Business \& Industrial Marketing. 2004, 19(3): 197.

Sawhney, M., Gianmario, V. \& Prandelli, E. Collaborating to Create: The Internet as Platform for Customer Engagement in Product Innovation. Journal of Interactive Marketing. 2005, 19(4): 4-17.

Sekliuckienè, J. Organizacijos ištekliu ịveiklinimo siekiant konkurencinio pranašumo modelis. Daktaro Disertacija: Socialiniai Mokslai, Vadyba ir Administravimas (03S). Kauno Technologijos Universitetas, 2006, 160p.

Tanev S.; Thomsen M. \& Ma, Z. Value CoCreation: From an Emerging Paradigm to the Next Practices of Innovation. ISPIM Conference Proceedings, Quebec, 2010.

Tanev, S.; Knudsen, M. \& Gerstlberger, W. Value Co-Creation as Part of an Integrative Vision for Innovation Management. Open Source Business Review Online Journal. 2009.

Tapscott, D. \& Williams, A. Wikinomics: How Mass Collaboration Changes Everything. New York: Portfolio, 2006.

Thomke, S. \& von Hippel, E. Customers as Innovators: A New Way to Create Value. Harvard Business Review. 2002, 80(4): 7481.

Tijūnaitienė R.; Šidlauskienè J.; Šerikova A. \& Toleikiene R. The Roles of Customer Participation in Co-Production of Planning the Furniture Services. Ekonomika ir 
Vadyba: Aktualijos ir Perspektyvos. 2009, 1(14): 290-300.

Urban, G. L.; Hauser, J. R.; Qualls, W. J.; Weinberg, B. D. et al. (1997). Information Acceleration: Validation and Lessons From the Field. JMR, Journal of Marketing Research. 1997, 34(1): 143-153.

Vargo, S. Customer Integration and Value Creation - Paradigmatic Traps and Perspectives. Journal of Service Research. 2008, 11(2): 211-215.

Vargo, S. L. \& Lusch, R.F. Evolving to a New Dominant Logic for Marketing. Journal of Marketing. 2004, 68(1): 1-17.

Verhoef, P. C.; Langerak F. \& Donkers, B. Understanding Brand and Dealer Retention in the New Car Market: The moderating role of brand tier," Journal of Retailing. 200783 (1).97-113.

von Hippel, E. Perspective: User Toolkits for Innovation. Journal of Product Innovation Management. 2001, 18: 247-257.
Walter, A. \& Ritter, T. The Influence of Adaptations, Trust, and Commitment on Value-creating Functions of Customer Relationships. Journal of Business \& Industrial Marketing. 2003, 18(4/5): 353-365. Warnke, P.; Weber, M. \& Leitner, K.H. (2008). Transition Pathways Towards User Centric Innovation,.International Journal of Innovation Management. 2008, 12(3): 489510.

Windisch, K. Co-Creation and the Ethics of Stakeholder Engagement for Value Creation. Doctoral Dissertation. Aarhus University, Business and Social Sciences, 2011, 1-118.

Yi, Y. \& Gong, T. The Development and Validation of a Customer Value CoCreation Behavior Scale. Global Marketing Conference, 2010-09-09 - 2010-09-12. Tokyo, 2010.

Zwick, D; Bonsu, S. \& Darmody, A. Putting Consumers to Work: Creation and New Marketing Govern-Mentality. Journal of Consumer Culture. 2008, 8(2): 163-196.

\title{
VERTĖS KŪRIMO KARTU SU VARTOTOJAIS PROCESO MATAVIMAS IR VALDYMAS: TEORINIŲ MODELIŲ APŽVALGA
}

\author{
Monika Skaržauskaitė \\ Mykolo Romerio universitetas, Lietuva, skarzauskaite@mruni.eu
}

Santrauka. Tikslas: per paskutininosius metus tradiciniai verslo procesai ir vertès kürimo büdai pasikeitè dèl didžiulio kiekio žiniu ir informacijos apie organizacijas prieinamumo išoriniams veikejams. Naujai igytos žinios leido atsirasti esminiams rinkodaros supratimo pokyčiams - pradètas akcentuoti abipusis vertès kürimas tobulinant ir kuriant produktus bei paslangas. Šio straipsnio tikslas yra pateikti holistini požiürį ż vertés kürimo kartu su vartotojais koncepcija bei egzistuojančius teorinius matavimo ir valdymo modelius atliekant mokslinès literatūros analizę ir integruojant skirtingus požiürius. Straipsnyje pateikiami svarbiausi ir aktualiausi literatūros apžvalgos ir analizés rezultatai daugiausia dèmesio sutelkiant i pasikeitusius vartotoju ir organizaciju vaidmenis. Šiuo straipsniu siekiama prisidèti prie moksliniu tyrimu srauto, siekiančio išaiskinti vertes kürimo kartu su vartotojais matavimo büdus bei gauti žiniu apie tai, kaip padidinti organizacijos efektyvuma ir rasti naujus büdus vertei kurti. Metodologija: teorine literatūros šaltiniu analizé ir sintezè. Atsižvelgiant į tyrimo 
objekto naujuma ir sudetinguma šio tyrimo pobūdis yra apžvalgomasis. Tyrimo ribotumas: tyrimo ribotumas slypi literatūros apžvalgos prigimtyje, nes tyrimo metu autorius turi visiškai pasikliauti anksčiau paskelbtais bei prieinamais moksliniais straipsniais. Rezultatai: analize atskleidè, kad danguma šaltiniu tyrinejja proceso ypatumus vartotoju pusëje, tačiau tik nedidele dalis šaltiniu analizuoja organizacini indeli z bendros vertès kürima su vartotojais bei büdus ji matuoti ir valdyti. Dar svarbiau, kad esami moksliniai tyrimai remiasi koncepciniu modeliu kürimu ir nedidelès apimties kokybine bei atveju analize. Praktine reikšmé: tyrimas gali büti laikomas pirmu žingsniu link modelio, matuojančio organizacijos indèlio $\dot{i}$ vertés kartu su vartotojais kürimo procesa, kürimo bei jo empirinio išbandymo. Tyrimo tipas: literatūros apžvalga.

Reikšminiai žodžiai: vertès kürimas kartu su vartotojais, socialinès technologijos, vertès kūrimo modeliai. 